\title{
THE MODERN HISTORY OF TORT REMEDIES IN ENGLAND AND WALES
}

\author{
Paul Mitchell ${ }^{*}$
}

I.

The modern history of tort remedies, which - for the purposes of this chapter - stretches from the final decade of the nineteenth century to the beginning of the twenty-first, has been much studied. Or, rather, aspects of it have been much studied. For the law of torts is such a miscellaneous and variegated category of wrongs that generalisations about its remedies have not appealed to legal researchers. Judges, as we shall see, have not always been so cautious. But the fact remains that, examined as a whole, the modern history of tort remedies has attracted relatively little attention.

This chapter aims to stimulate new interest in the subject, by proposing that illuminating general insights into the modern history of tort remedies can be obtained by paying attention to three inter-related and overarching themes. The first is the role of history in shaping, constraining, defining and - occasionally - suppressing modern developments in tort remedies. The second is the extraordinary significance of legal categories at multiple levels, ranging from the distinctions between different heads of damages to the distinctions between different torts and, ultimately, between tort and non-tort. These categories, it should be emphasised, are not mere convenient repositories for organising information, they have invited and encouraged distinctive patterns of legal development. Finally there is the tension between rationalism and irrationalism. As Terry Eagleton has put it, 'The modern age has been continually divided between a sober but rather bloodless rationalism on the one hand, and a number of enticing but dangerous forms of irrationalism on the other.' ${ }^{1}$ This, as we shall see, is an uncannily accurate description of the modern history of tort remedies, from an author who had very different subjects in mind. ${ }^{2}$

In the discussion which follows, particularly striking examples of history, categories and rationalism are identified and analysed. As readers will quickly realise, these factors often support and reinforce each other, or happen to apply simultaneously, or conflict with each other - indeed, their interactions frequently offer the most interesting case studies. This makes it difficult to single out particular instances of legal development as illustrations of only one factor at work, but the broad theme of the discussion is to move from relatively simple examples to more complex and multifaceted ones.

\footnotetext{
${ }^{*}$ Professor of Laws, UCL.

${ }^{1}$ How to Read a Poem (Blackwell, 2007) 21.

2 The passage continues: 'Poetry, however, offers to bridge this gap.'
} 
II.

The constraining power of history can be seen most clearly when an opportunity to make a new start is deliberately spurned. This was the case in Shelfer $v$ City of London Electric Lighting Company $^{3}$, where the Court of Appeal laid down guidelines concerning the courts' exercise of their discretion to award damages in lieu of an injunction in nuisance cases. The discretion had been conferred by a relatively recent statute, the Chancery Amendment Act 1858 (Lord Cairns' Act), but the Court of Appeal was not tempted to innovate. Drawing heavily on historical assumptions about the role of the Court of Chancery in nuisance cases, the Court of Appeal defined the circumstances in which it would award damages in lieu of an injunction very restrictively, using the following formula: ${ }^{4}$

it may be stated as a good working rule that -

(1) If the injury to the claimant's legal rights is small,

(2) And is one which is capable of being estimated in money,

(3) And is one which can be adequately compensated by a small money payment,

(4) And the case is one in which it would be oppressive to the defendant to grant an injunction: -

then damages in substitution for an injunction may be given.

The prominence of, and corresponding emphasis on, the conjunctions at the start of factors (2)(4) gives a sharp sense of the Court's determination to constrain the potential play of the discretion. The Shelfer decision also illustrates the force of history in a different sense, for, although the Court of Appeal presented itself as merely offering guidance ('a good working rule') to later courts, its advice quickly took on the texture of a mandatory precondition. Twentieth century courts applied the Shelfer criteria in an increasingly dogmatic way ${ }^{5}$, until, eventually, the Supreme Court was driven to order moderation. ${ }^{6}$ What had been expressed as a broad statutory discretion had been encumbered with a non-negotiable prerequisite.

A similar judicial commitment to a particular approach to granting injunctions could also be seen in defamation cases. The leading case of Bonnard $v$ Perryman ${ }^{7}$ was decided only a couple of years after Shelfer, and, as with Shelfer, what the Court of Appeal laid down as guidance quickly acquired the status of a rule. Indeed, the 'rule' in Bonnard $v$ Perryman has proved more resilient even than the rule from Shelfer's case, having survived a recent attempt to limit its universal application. ${ }^{8}$ But where the decision in Bonnard $v$ Perryman is rather different to Shelfer's case is that it emphasises a default position of refusing an injunction for a threatened

\footnotetext{
${ }^{3}$ [1895] 1 Ch 287.

4 ibid, 322-323.

${ }^{5}$ Eg Watson v Croft Promo-Sport Ltd [2009] EWCA Civ 15.

${ }^{6}$ Lawrence v Fen Tigers Ltd [2014] UKSC 13, [2014] AC 822.

${ }^{7}$ [1891] 2 Ch 269.

${ }^{8}$ Greene v Associated Newspapers Ltd [2004] EWCA Civ 1462, [2005] QB 972.
} 
tort. In terms that were extraordinarily prescient, the Court of Appeal said that 'The right of free speech is one which it is for the public interest that individuals should possess, and, indeed, that they should exercise without impediment, so long as no wrongful act is done'. ${ }^{9}$ The Human Rights Act was still over a century away.

III.

For the purposes of this essay the historical roots and longevity of Bonnard v Perryman are, of course, significant. But the case also illustrates the importance of categories. For, when the Court of Appeal invoked the 'public interest' to support its decision, it drew on a value with the potential to shape and inform other aspects of tort remedies. It might have been thought, for instance, that potential defamation defendants could be inhibited from publication by the prospect of unlimited, unpredictable damages awards, and that, surely, suggested a role for ideas about the public interest in the way that damages were assessed. ${ }^{10}$ There is no hint of this in the Court of Appeal's decision in Bonnard v Perryman or in later cases applying the Bonnard rule. Nor does the importance of the public interest seem to have unsettled the approach to injunctions for other torts. No-one, it seems, was immediately troubled by the lack of a public interest criterion in the Shelfer formula: it would not be until the 1970s, in an analysis that was deliberately designed to break with the past, that Lord Denning would take up the significance of the public interest in such cases. ${ }^{11}$ This kind of highly fragmented legal development is only maintainable where the distinctions between categories are regarded as so firm, inevitable natural, even - that they automatically invalidate attempts to make comparisons or to draw contrasts.

IV.

At the highest level of generality, the logical consequence of a commitment to the inevitability and naturalness of categorical divisions is that comparisons or contrasts between tort and other remedial mechanisms are strictly irrelevant, and can be disregarded. This attitude can be seen particularly vividly in the emergence and operation of a workmen's compensation system which, despite having obvious aims in common with tort, had essentially no influence on tort principles. It was not as if the compensation system had been created without regard to the existing tort remedies. On the contrary, it was the very limited availability of tort damages for workplace injury which had created the rationale for the compensation scheme. ${ }^{12}$ The particular

\footnotetext{
9 ibid 284.

${ }^{10}$ R Pound, 'Equitable Relief Against Defamation and Injuries to Personality' (1915-1916) 29 Harvard Law Review 640, 650-651.

${ }^{11}$ Miller v Jackson [1977] 3 All ER 338. Note especially the headings at 342 and 343: 'The law in the $19^{\text {th }}$ century', 'The law in the $20^{\text {th }}$ century'.

${ }^{12}$ On the emergence of the workmen's compensation system see PWJ Bartrip and SB Burman, The Wounded Soldiers of Industry; Industrial Compensation Policy 1833-1897 (Clarendon 1983); WR Cornish and G de N Clark, Law and Society in England 1750-1950 (Sweet \& Maxwell 1989) ch 7; V Markham Lester, 'The employers' liability/workmen's compensation debate of the 1890s revisited' Historical Journal 44, 2 (2001) 471;
} 
problem was the defence of common employment, which eliminated an employer's liability for injury caused tortiously by one workman to a fellow workman. Nineteenth century reform initiatives sought to curtail, or abolish completely, the common employment doctrine. The expansion of the electoral franchise in the final third of the nineteenth century, absorbing large numbers of working men, gave the issue political urgency, but the eventual solution was not a simple reform of the common law. Instead, employers became liable to compensate injured employees irrespective of fault on the part of the injurer - which was a significant advantage for claimants over the fault requirement in tort. But this advantage was rather offset by the fact that the level of compensation was lower than in tort, and that payments were made periodically, rather than as a lump sum.

Experience of the workmen's compensation system in action showed that it was a less than perfect solution. The lengthy legislation spawned complex case-law; and the large quantity of litigation between workmen and their employers seems to have contributed to poisoning industrial relations. But the fact remained that that the workmen's compensation system represented an entirely new and radical approach to providing compensation for personal injuries; such an approach, one might have thought, could offer a critical perspective on the operation of tort remedies. That it did not do so is testament to the power of legal categories. A writer as wide-ranging and intellectually curious as Frederick Pollock told readers of his tort treatise that workmen's compensation cases 'throw no light on any principle of the law of torts'. ${ }^{13}$ The same authorial assumption could also be seen in P H Winfield's The Province of the Law of Tort, which was a more self-consciously theoretical investigation of tort liability. ${ }^{14}$ The omission of workmen's compensation caught the eye of PA Landon, who, in a review of the book, commented disapprovingly: ${ }^{15}$

it is obvious that everyone intending to practise in common law cases must know [workmen's compensation] thoroughly, and it is so intimately bound up with the question of the employer's liability to his employee that it is most fittingly set out... as part of the law of tort.

Winfield's reponse was to admit that practitioners did, indeed, need a thorough knowledge of workmen's compensation. But, for Winfield, it was impracticable to provide that thorough knowledge in a tort book. 'May one remind Mr Landon', he wrote, 'that in about ten years there were 1,200 decisions in appellate courts alone on these Acts? ${ }^{\prime 16}$

What is particularly noticeable about this exchange is its utterly pragmatic basis. Landon wanted expositions of tort law to include expositions of workmen's compensation because practitioners had to be able to navigate both systems, not because the workmen's compensation scheme prompted critical reflection on the tort system. Winfield accepted Landon's assessment

\footnotetext{
P Bartrip 'The impact of institutions and professions on compensation for occupational injury in England' in $\mathrm{P}$ Mitchell (ed), The Impact of Institutions and Professions on Legal Development (CUP 2012) 36.

${ }^{13}$ F Pollock, The Law of Torts tenth edition (Stevens 1916) 114.

${ }^{14}$ F P[ollock], review of Winfield, The Province of the Law of Tort (1931) 47 LQR 588 noted the theoretical emphasis with distaste.

${ }^{15}$ PA Landon, 'The Province of the Law of Tort' (1931) 8 Bell Yard 19, 31.

${ }^{16}$ P Winfield, 'The Province of the Law of Tort: A Reply' (1932) 9 Bell Yard 32, 38.
} 
of practitioners' needs, but the only worthwhile treatment of workmen's compensation that he could imagine was one in which the 1,200 appellate decisions were accounted for, and that was beyond the scope of a tort book. ${ }^{17}$ It would take another forty years and - in Patrick Atiyah - a writer of extraordinary originality and brilliance, before the compensation system perspective would be used to construct a comprehensive critique of tort doctrines. ${ }^{18}$

V.

History and categories featured prominently in the single most important judicial pronouncement on tort remedies in the modern era - Lord Devlin's speech in Rookes $v$ Barnard. ${ }^{19}$ Here, in a rare judicial foray into the universal principles of tort remedies, Lord Devlin laid down the two situations in which tort damages punishing a defendant could legitimately be awarded. ${ }^{20}$ These were, first, where there had been oppressive, arbitrary or unconstitutional action by the servants of the government; and, second, where the defendant had calculated that by committing the tort he would make a profit exceeding any damages liability. As Lord Devlin frankly acknowledged, these two situations were significantly narrower than the circumstances in which exemplary damages had previously been awarded. Indeed, the sense is that his Lordship would have preferred to go further, and to eliminate the availability of exemplary damages from tort altogether. The weight of precedent, however, persuaded Lord Devlin to stop short of total abolition.

What lay behind this new approach to exemplary damages was the desire to rationalise. The function of tort was to compensate; punishment was a matter for the criminal law; and tort principles punishing defendants were, therefore, unsightly anomalies. In this analysis we should notice the particular kind of rationality in play: it is a rationality derived entirely from the categories of tort and criminal law. The argument is circular, because it is the existence of the criminal law which, in and of itself, is relied on as making punitive elements in tort foreign: there is no attempt to assess whether the numerous earlier (cited) cases on exemplary damages in tort reflect, and justify, a conception of tort remedies that goes beyond the merely compensatory. It is also important to notice the implicit appeal to purity: because tort is compensatory, any punitive doctrine is a contaminant, and must, therefore, be removed. The logic of the metaphor of purity leaves no room for arguments about whether doctrinal 'impurity' is a price worth paying for any societal benefits (such as deterrence) that might flow from allowing tortious punitive damages to be awarded: the combination of categories and rationalism provides a categorical answer. Finally, we might note the interaction between history and categories in Lord Devlin's reasoning. As we have seen, Lord Devlin felt inhibited about abolishing exemplary damages altogether because of the weight of precedent; but he felt justified in his decision to scale back exemplary damages because many of those earlier cases,

\footnotetext{
${ }^{17}$ For further discussion of Winfield's ideas, including his debate with Landon, see P Mitchell, A History of Tort Law 1900-1950 (CUP 2015) 19-32.

18 PS Atiyah, Accidents, Compensation and the Law (Weidenfeld \& Nicolson 1970).

19 [1964] AC 1129.

20 ibid, 1126.
} 
he suggested, could be 'more easily justified' as compensatory awards. ${ }^{21}$ The key point here was the idea of aggravated damages, i.e. damages reflecting the additional aggravation of the harm suffered by the claimant - for instance, the additional distress suffered by defamation claimants when a false allegation is insisted to be true right up to the start of the trial, at which point the defendant abruptly abandons the defence. Using this concept of aggravated damages, the outcomes in several cases, though not the judicial language used to support them, could be seen as acceptably compensatory - history could be rewritten to reinforce the logic of legal categorisation.

VI.

The rationale of compensation, which was so powerful in Rookes $v$ Barnard, dominated judicial thinking about tort damages throughout the twentieth century. But, as we shall now see, what judges understood as being entailed by that commitment to compensation varied very significantly. The central difficulty was over the relationship between compensation and loss; and the question could be expressed in two, equally problematic, forms. First, what counted as a loss for the purposes of compensation?; second, was all such identifiable loss to be compensated?

One of the earliest, and most eloquent, analyses of the question in its first form was provided by Lord Halsbury LC in The Mediana. ${ }^{22}$ There the defendants had negligently collided their vessel with a lightship owned by the claimants, the Mersey Docks and Harbour Board. The lightship sank. The claimants deployed their standby vessel, which they maintained for just such emergencies. As part of their claim for damages they sought to recover for 'the loss of use of the [sunken] lightship, or hire of the services of the [standby] lightship'. ${ }^{23}$ The defendants challenged this head of claim, emphasising that the claimants had incurred no additional expense in using the standby.

The House of Lords unanimously upheld the claimants' entitlement to damages on this head. For the Earl of Halsbury LC, the key point was that the claimants had been deprived of their vessel $^{24}-$

When I say deprived of their vessel, I will not use the phrase 'the use of the vessel'. What right has a wrongdoer to consider what use you are going to make of your vessel?.. Supposing a person took away a chair out of my room and kept it for twelve months, could anybody say you had a right to diminish the damages by showing that I did not usually sit in that chair, or that there were plenty of other chairs in the room? The proposition so nakedly stated appears to me to be absurd; but a jury have very often a very difficult task to perform in ascertaining what should be the amount of damages of that sort. I know very well that as a matter of

\footnotetext{
21 ibid 1229.

22 [1900] AC 113.

23 ibid 114.

24 ibid 117.
} 
common sense what an arbitrator or a jury very often do is to take a perfectly artificial hypothesis and say, 'Well, if you wanted to hire a chair, what would you have to give for it, for the period'; and it that way they come to a rough sort of conclusion as to what damages ought to be paid for the unjust and unlawful withdrawal of it from the owner. Here... the broad principle seems to me to be quite independent of the particular use the plaintiffs were going to make of the thing that was taken, except - and this I think has been the fallacy running through the arguments at the bar - when you are endeavouring to establish the specific loss of profit, or of something that you otherwise would have got which the law recognises as special damage. In that case you must shew it...

This principle, he made clear, applied generally - it did not depend on the particular form of action involved.

Here, then, was an important general statement about the difference between compensation, loss and expenditure in cases of deprivation of property. 'Loss' did not mean 'financial loss'; expenditure was recoverable as 'special damage'; and, more subtly, the valuation of a deprivation was not to be discounted (or, presumably, inflated) by arguments about how the claimant might have used the asset.

By the end of the twentieth century all of these propositions had been abandoned or heavily qualified. The proposition that 'loss' did not mean 'financial loss' lasted just over twenty years: in Admiralty Commissioners $v$ Owners of the Steamship Valeria ${ }^{25}$ the House of Lords held that the decision in The Mediana applied only to vessels that were not profit-earning. The loss of an ordinary commercial ship was to be equated with the loss of profit (if any) during the period of deprivation.

Next to go was the claim that the statements in The Mediana applied regardless of the form of action: in Strand Electric and Engineering Co Ltd v Brisford Entertainments Ltd ${ }^{26}$ the Court of Appeal declined to apply The Mediana to a claim for detinue. The claim concerned a commercial chattel, but the Court did not mimic the House of Lords' approach in The Valeria and limit recovery to proved loss of profit. Instead, it emphasised that the defendants had made use of the chattels, and that the damages award should, therefore, reflect the defendants' gain. For Denning LJ, 'It [was] an action against [the defendant] because he has had the benefit of the goods. It resembles, therefore, an action for restitution rather than an action of tort. ${ }^{27}$ Denning LJ's colleagues were not quite so outspoken, but it is now recognised (and accepted) that, for some torts - mainly involving property rights - gain-based awards are available. ${ }^{28}$ In one sense, of course, this reflects the power of legal categories to shape legal content - it is not at all obvious, for instance, why the victim of an intentional tort to the person such as battery or false imprisonment should not have the option of a gain-based award. But, in another sense, the emergence of gain-based damages for proprietary torts demonstrates that the insistence on

\footnotetext{
25 [1922] 2 AC 242

${ }^{26}$ [1952] 2 QB 246.

27 ibid 255.

${ }^{28}$ H Beale (gen ed), Chitty on Contracts thirty second edition (Sweet \& Maxwell 2015) 29-148 .
} 
legal categories was less than systematic: for it could be argued that, just as Rookes v Barnard showed that punitive damages were the proper province of criminal law, so gain-based awards should have been the province of the law of unjust enrichment. The courts, however, have not acceded to such arguments. Perhaps the main explanation lies in history - no one in the modern era could doubt the existence and basic shape of criminal law, but the history of unjust enrichment is rather different. The very existence of a distinct law of restitution was not authoritatively established until the early $1990 \mathrm{~s}^{29}$, and its basic shape is still being settled. Even the name of the category has evolved recently, with 'unjust enrichment' being preferred as a more accurate indication of its contents ('restitution' unhelpfully denotes both claims in unjust enrichment and gain-based awards for wrongs). ${ }^{30}$ So the argument that gain-based damages should not be available in tort because that was a matter for unjust enrichment would have had none of the immediate appeal and force that the parallel argument against exemplary damages had.

Lord Halsbury's point about the irrelevance of the claimant's potential use of the asset during the period he was deprived of it was, of course, curtailed by the House of Lords' decision in The Valeria that the loss of a commercial vessel was to be valued by the profit it would have earned. But it was also undermined, in a broader way, by the courts' approach to the assessment of loss of amenity in personal injury cases. The loss of amenity award was conceived as compensating the claimant for the fact that, as a result of this injury, certain activities were either impossible or significantly curtailed. In fixing the amount of the award, the court would have regard to the likelihood of the claimant having engaged in those activities. Thus, as Diplock LJ explained in Wise $v$ Kaye ${ }^{31}$, an active young man would receive a higher loss of amenity award for the loss of his leg than 'a young man of the same age but of scholarly tastes who spends his leisure hours reading or listening to music. ${ }^{32}$

VII.

Diplock LJ's explanation of damages for loss of amenity in Wise $v$ Kaye occurred in the course of a judgment that argued that such awards were misconceived. For Diplock LJ the underlying purpose of the non-pecuniary element in a personal injury award was to provide the claimant with the means to attain happiness in future. Thus, it made sense to offer the active young man more than the scholarly young man for losing a leg, but only because the active young man's happiness was more dependent on his physical fitness than the scholarly man's. If, however, the claimant had no prospect of using the award to attain happiness - as was the case in Wise $v$ Kaye, where the claimant was in a coma - an award of damages served no purpose, and should not be made.

\footnotetext{
${ }^{29}$ Lipkin Gorman (A Firm) Ltd v Karpnale [1991] 2 AC 548.

${ }^{30} \mathrm{C}$ Mitchell, P Mitchell and S Watterson (ed), Goff and Jones on the Law of Unjust Enrichment ninth edition (Sweet \& Maxwell 2016) 1-01 - 1-04.

${ }^{31}$ [1962] 1 QB 638.

32 ibid 665.
} 
Diplock LJ, however, was in the minority, and his argument that loss of amenity damages should be denied to claimants who were not able to make use of them have not been taken up by later judges. Loss of amenity continues to be compensated on the basis of the claimant's deprivation of function. Indeed, the most recent pronouncement on this issue, by the Court of Appeal in Heil $v$ Rankin $^{33}$, reaffirmed the centrality of the compensatory approach to nonpecuniary damages and endorsed a significant increase in their amount so as to ensure that they were 'not... out of accord with what society as a whole would perceive as being reasonable.'34

In taking this approach the Court was not only invoking the twentieth century tenet that tort damages awards must compensate for loss; it was also obeying an imperative that had come to be associated with that tenet, namely, that judges must set out to measure that loss as precisely as possible. The best illustration of this imperative at work is in claims for future pecuniary loss (typically lost earnings and the cost of medical treatment) in personal injury cases. Over the course of the twentieth century the law moved from a position of impressionistic assessment to one in which actuarial tables were used for life expectancy, and the House of Lords was called on to decide how, precisely, it should be assumed that a claimant would invest a damages award. $^{35}$

But, seductive as the rationale of precise compensation was, tort damages could not completely embrace it. Non-pecuniary damages did their best, but judges also had to acknowledge that it was impossible to put a value on pain, suffering and loss of amenity with anything like scientific precision. ${ }^{36}$ The solution was to rely on earlier judicial awards to achieve at least some measure of consistency, and the courts were undoubtedly helped in this task by the appearance of reports of quantum awards in Current Law and Kemp and Kemp's The Quantum of Damages in Personal Injury Claims from the mid-century onwards. ${ }^{37}$ Later the Judicial Studies Board published Guidelines in which the accountancy ideal was nearly reached: for each type of injury a range of figures (derived from previous awards) was provided. ${ }^{38}$ The result is a kind of faux rationalism, in which the figures' real authority is derived from nothing more exalted than 'safety in numbers'.

The compensatory rationale also had its dangers. For if it was true that personal injury damages compensated for losses, new heads of damage could be identified by ingenious advocates, and it was difficult to say why they should not be recoverable. Perhaps the best illustration is the emergence of damages for loss of expectation of life, which were first awarded in Flint $v$ Lovell in $1934 .{ }^{39}$ The basic idea was simple enough: the victim of an accident who has either been

\footnotetext{
33 [2000] EWCA Civ 187, [2001] QB 272.

34 ibid [27].

${ }_{35}$ Actuarial Tables with explanatory notes for use in Personal Injury and Fatal Accident cases (HMSO 1984) (the 'Ogden tables'); Wells $v$ Wells [1999] 1 AC 345.

${ }^{36}$ Eg Heil (n 33) [23], [25].

${ }^{37}$ D Kemp and S Kemp, The Quantum of Damages in Personal Injury Claims (Sweet \& Maxwell 1954). The value of the book (and some of its shortcomings) are highlighted in a review by G Ellenbogen (1955) 18 MLR 642.

38 Judicial Studies Board, Guidelines for the Assessment of Damages in Personal Injury Cases (Blackstone 1992) ; the most recent edition is: Judicial College, Guidelines for the Assessment of Damages in Personal Injury Cases (OUP 2017).

${ }^{39}$ [1935] 1 KB 354.
} 
killed, or has suffered a reduction in life expectancy as a result of his injuries, has been deprived of life, and this is a loss for which the defendant should pay compensation. Within six years, however, this formulation had proved so disastrously unworkable that the House of Lords intervened. ${ }^{40}$ They recast the award as being for loss of future happiness; awards should thenceforth be more modest, but required 'the Court to be satisfied that the circumstances of the individual life were calculated to lead, on balance, to a positive measure of happiness, of which the victim has been deprived by the defendant's negligence. ${ }^{41}$ It might, perhaps, be possible to detect a note of valiant rationalism in this exhortation to draw up a balance sheet of the claimant's prospects of pleasure and pain. But it is difficult to avoid the sense, so well expressed by Otto Kahn-Freund, that the House of Lords had 'resort[ed] to what one is almost tempted to call the subterfuge of laying down a theory of valuation which involves in effect the complete jettisoning of all standards of rational assessment' ${ }^{42}$

Finally, we should notice that the desire for tort damages to be itemised with the precision of a balance-sheet was not felt universally. Some torts did not even require a claimant to prove any loss: having established the elements of liability for these torts, claimants then left it to the courts to assess their damages 'at large'. The most significant example was libel. In the final decade of the twentieth century pressure would grow for libel awards to be more moderate and to have (broad) regard to non-pecuniary personal injury damages, but there is still no requirement to account for the final figure in any detail. ${ }^{43}$ The insistence on rationalism had its limits, it seems.

VIII.

The main reason why late twentieth century impressionistic libel awards could co-exist with late twentieth century personal injury assessments was that libel awards were often made by juries, while personal injury awards were left to judges alone. It had not always been that way. Until the early twentieth century actions for defamation, negligence and many other torts were decided by juries, and it was only the critical shortage of manpower caused by the First World War which forced a change. ${ }^{44}$ By the Juries Act 1918 all matters before the High Court were to be tried without a jury, except claims for fraud, libel, slander, malicious prosecution, false imprisonment, seduction and breach of promise of marriage. The Administration of Justice Act 1925 abolished these restrictions; but the Administration of Justice (Miscellaneous Provisions) Act 1933 reintroduced similar controls. Claims for fraud, libel, slander etc remained matters

\footnotetext{
${ }^{40}$ Benham v Gambling [1941] AC 157.

41 ibid 166-167 (Lord Simon LC).

42 O Kahn-Freund, 'Expectation of Happiness' (1941-1942) 5 MLR 81.

${ }^{43}$ Moderation: Sutcliffe v Pressdram Ltd [1991] 1 QB 153, Gorman v Mudd (CA Civ Div 15 October 1992), Rantzen v Mirror Group Newspapers (1986) Ltd [1994] QB 670. Regard to personal injury damages: John v MGN Ltd [1997] QB 586, Kiam v MGN Ltd [2002] EWCA Civ 43, [2003] QB 281, The Gleaner Co Ltd v Abrahams [2003] UKPC 55, [2004] 1 AC 628.

${ }^{44} \mathrm{R}$ M Jackson, ‘The Incidence of Jury Trial During the Past Century’ (1937) 1 MLR 132.
} 
for jury trial; in other cases the court had an unfettered discretion to decide how the action should be tried. ${ }^{45}$

Judges were deeply respectful of jury awards, and would venture to interfere with them only if the amount was out of all proportion to the wrong. ${ }^{46}$ This was not merely a point of procedural etiquette. As Atkin LJ put it, in a case decided in 1922 (when the Juries Act 1918 restrictions still applied), 'Trial by jury... is an essential principle of our law. It has been the bulwark of liberty, the shield of the poor from the oppression of the rich and powerful. ${ }^{47}$ Bankes LJ, in the same case, called for the immediate reinstatement of trial by jury, claiming that 'the standard of much that is valuable in the life of the community has been set by juries in civil cases. ${ }^{48}$ Even as late as 1954 , when jury trials for personal injury were very much the exception, the Court of Appeal would observe that 'it has been said more than once that a judge sitting by himself is not in as good a position to assess damages as are twelve members of a jury. ${ }^{49}$

At least part of the attraction of jury trials for judges was that a jury's verdict relieved judges of the obligation to rationalise or justify the court's conclusion. The jury simply announced its figure and that was that. Where the award included elements that could not be rationally accounted for, the jury's role was particularly warmly appreciated. As the Earl of Halsbury LC put it in The Mediana: ${ }^{50}$

Of course the whole region of inquiry into damages is one of extreme difficulty. You very often cannot even lay down any principle upon which you can give damages; nevertheless, it is remitted to the jury, or those who stand in place of the jury, to consider what compensation in money shall be given for what is a wrongful act. Take the most familiar and ordinary case: how is anyone to measure pain and suffering in moneys counted? Nobody can suggest that you can by any arithmetical calculation establish what is the exact amount of money which would represent such a thing as the pain and suffering which a person has undergone by reason of an accident. In truth, I think it would be very arguable to say that a person would be entitled to no damages for such things. What manly mind cares about pain and suffering that is past? But nevertheless the law recognises that as a topic upon which damages may be given.

It is worth pausing for a moment over this quotation, for it perfectly encapsulates the division between rationalism and irrationalism which is such a key feature of the modern history of tort remedies. The rationalistic commitment to compensate all losses (including pain and suffering) requires an award to be made; but no rational basis exists for the quantification of the award. Fortunately, however, the question can be left to the jury; and, although their decision-making

\footnotetext{
${ }^{45}$ Hope v Great Western Railway Company [1937] 2 KB 130.

${ }^{46}$ Praed v Graham (1889) 24 QBD 53.

${ }^{47}$ Ford v Blurton (1922) 38 TLR 801, 805.

$48 \mathrm{ibid}, 803$. Note, however, Scrutton LJ's markedly less rousing comments about jury trial on the same page.

${ }^{49}$ Bocock v Enfield Rolling Mills Ld [1954] 1 WLR 1303.

${ }^{50}$ [1900] AC 113, 116-117.
} 
is both arbitrary and secret, this irrational method allows the compensatory rationale to be respected. Irrationality comes to the rescue of rationality. But the rescue comes at a price, because the jury's convenient involvement allows the deeper, more troubling question hinted at in the penultimate sentence - namely whether pain and suffering should be compensated at all - to be evaded.

IX.

Judges' grateful reliance on juries for the assessment of damages would be tested to its limits in a flurry of cases concerned with loss of expectation of life. As explained above, the basis of this head of damage was that a victim of a fatal accident, or a claimant with reduced life expectancy as a result of the tort, had lost a valuable asset in the form of a longer life. The courts accepted that this loss was in principle recoverable. But then it became necessary to quantify the loss, and that was when the trouble started.

Judges sitting alone at first instance quickly realised that they were out of their depth. Almost immediately, questions of theology raised their heads, with Hawke $\mathbf{J}$ acknowledging that 'There are people who think, or say they think, that they must be better off in Heaven than they would be in this life. ${ }^{51}$ One judge cautioned himself against 'over-analysis' ${ }^{52}$, and another bravely sought comfort in Lord Wright's comment that, although the measure of damages could not be ascertained with 'any accuracy', 'that is no reason to say that it cannot be done and an effort has to be made to do it. ${ }^{53}$ If ever there was a situation where juries' help was urgently needed, this was surely it.

But when juries did become involved, it turned out that they too would struggle to value lost expectations of life. One vivid example concerned three year-old children. In Shepherd v Hunter $^{54}$ the jury's award for loss of expectation of life was $£ 90$, a figure which the Court of Appeal found so shockingly low as to be 'clearly erroneous'. ${ }^{55}$ The decision was particularly notable for Slesser LJ's indignant rejection of the defendant's argument 'that the local consideration that this infant lived in Lancashire and that this was a Manchester jury might have brought about this result. ${ }^{, 56}$ The possibility that the jury might have made an all too accurate assessment was not to be tolerated. In Bailey $v$ Howard $^{57}$, by contrast, a jury awarded $£ 1000$, which the Court of Appeal said could not be challenged. MacKinnon LJ hinted at the difficulties that the law had got itself into, when he observed that 'I really have no view whether I think it too much or too little, because I am perfectly incapable of forming any estimate of what is the proper amount to be awarded. ${ }^{58}$ Scott LJ pinned his hopes on 'the gradual working

\footnotetext{
${ }^{51}$ Dransfield v British Insulated Cables Ltd [1937] 4 All ER 382, 389.

${ }^{52}$ The Aizkarai Mendi [1938] P 263, 275 (Langton J).

${ }^{53}$ Feay v Barnwell [1938] 1 All ER 31, 34 (Singleton J), paraphrasing Lord Wright in Rose v Ford [1937] AC 826, 849-850.

${ }^{54}$ [1938] 2 All ER 587.

55 ibid 589 (Greer LJ).

56 ibid 591.

${ }^{57}$ [1939] 1 KB 453.

58 ibid 459.
} 
out, chiefly through the common sense of juries, of the sort of figures that in English civilization of to-day are to be regarded as reasonable for damages under that particular head. ${ }^{59}$ As we have seen above, the House of Lords would soon curtail such a gradual working out by redefining the claim as one for lost happiness.

What the loss of expectation of life episode shows is that juries' common sense assessments could quickly degenerate into randomness, to an extent that the law - despite its acceptance of some degree of irrationality - found unbearable. It also hints at the difficulties which leaving questions to a jury would often conceal. There was simply no coherent way, for instance, to reconcile the Manchester jury's valuation of the lost life of a three year-old with the Middlesex jury's valuation of the same loss at $£ 1000 .{ }^{60}$ The law simply could not be open to these differences.

$\mathrm{X}$.

The powerful influence of history, traditional legal categories and a rationalistic commitment to compensation also tended to close off the law of tort remedies from wholesale reform. Statutory initiatives have tended to affirm and reinforce the basic model, rather than challenging it ${ }^{61}$, with more radical proposals never reaching the statute book. ${ }^{62}$ The failures of those more ambitious proposals offer object lessons in the political priorities and special interests at stake in this area, as well as highlighting some brilliantly effective lobbying. Attempts at radical judicial reform have also tended to stutter - the notable exception being Lord Devlin's speech in Rookes v Barnard - and academic writing seems to have had less impact than in other areas. Perhaps the best illustration of this latter point comes from the area with which we began this essay - injunctions for nuisance. In 1960 Ronald Coase published one of the most important law review articles of the twentieth century, in which, taking injunctions for nuisance as his central example, he showed how powerful and suggestive economic critiques of legal doctrines could be. ${ }^{63}$ Yet no reader of English twentieth century law reports could have the slightest idea that Coase's work existed. ${ }^{64}$

A large part of the explanation for this situation probably lies outside the law of remedies - in conventions of citation, the historically low status of academic writing, scepticism about the value of comparative materials, etc. ${ }^{65}$ In that sense the non-influence of Coase exemplifies

\footnotetext{
59 ibid 458. For further exploration of these cases, in the context of tort's treatment of children, see P Mitchell, $A$ History of Tort Law 1900-1950 (CUP 2015) 128-133

60 The reports of Bailey $v$ Howard in the Law Reports and the All England Reports ([1939] 1 KB 453 and [1938] 4 All ER 827) do not specify the venue of the trial. The report in The Times (15 December 1938), however, gives the location of the accident as being Greenford, Middlesex.

${ }^{61}$ For a notable exception see Damages Act 1996 s 2 (right to award periodical payments in certain circumstances).

${ }^{62} \mathrm{Eg}$ in respect of compensation for injury arising from road traffic accidents: P Bartrip, 'Pedestrians, Motorists and No-Fault Compensation for Road Accidents in 1930s Britain' (2010) 31 Journal of Legal History 45; P Bartrip, 'No-Fault Compensation on the Roads in Twentieth Century Britain' [2010] CLJ 263.

${ }^{63} \mathrm{R}$ Coase, 'The Problem of Social Cost' (1960) 3 Journal of Law and Economics 1.

${ }^{64}$ A Westlaw search for 'Coase' gives no relevant results in the twentieth century.

${ }^{65}$ N Duxbury, Jurists and Judges (Hart 2001).
} 
many of the most interesting unanswered questions in the modern history of tort remedies. It is instructive, worthwhile and sometimes even fascinating to map the roles of history, categories and rationalism. But to understand why these factors and ideals held such sway, the researcher inevitably has to travel beyond the law of remedies, and engage with questions about the operation of the legal system as a whole, and about the priorities, values and assumptions of its most influential participants. 